\title{
The Role of Benazir Bhutto in the Movement for the Restoration of Democracy: An Analysis
}

\author{
Amir Ahmed Khuhro and Ali Nawaz Soomro
}

\begin{abstract}
Pakistan is a democratic republic but has spent much time under military rulers, after a few years of independence Pakistan had faced three martial laws during 1958, 1969, 1977 and latest in 1999 by General Musharraf. During these martial laws some struggles were also raised against martial law and for restoration of democracy, even political parties made alliances against the martial laws, The aim of the research paper is to analyze the Former Prime Minister of Pakistan Benazir Bhutto's policies, politics and struggle and the role in the in the movement called Movement for the Restoration of Democracy (MRD) and how she fought against military dictator and mobilized the peoples of Pakistan to get their rights during dictatorship of General Muhammad Zia-ulHaq.
\end{abstract}

Index Terms-Democracy, military, politics, movement, alliance, election, martial law.

\section{INTRODUCTION}

The Former Prime Minister of Pakistan, Benazir Bhutto was born at Karachi on June $21^{\text {st }}$, 1953 , received her early education from Pakistan, and she graduated from Harvard University after that she did her Diploma in Foreign Affairs from Oxford University. She was the daughter of Zulifqar Ali Bhutto (the former President and the first elected Prime Minister of Pakistan); On the returning back to Pakistan on one hand, Benazir Bhutto was very much happy being the first elected student in the history of Pakistan as a President of Oxford Union Debating Society in UK and she was planning for her bright future in Pakistan, but at that time Pakistan was suffering from so many political problems, a big problem raised after the general election of 1970, in which the Awami National Party of ShaikhMujeeb-urRehaman won the majority seats but political powers were not transferred to them, in the result, the political problems were increased, due to which the leaders of East Pakistan decided to get freedom from their Western Wing and wanted a separate home land for Bengali people and "its independence was assured on December 16th, 1971"'[1].

Manuscript received March 10, 2013; revised May 11, 2013.

Amir Ahmed Khuhro is with Professor, Department of International Relations, Shah Abdul Latif University, Khairpur, Sindh, Pakistan (e-mail: amir.khuhro@salu.edu.pk).

Ali Nawaz Soomro is with Teaching Assistant, M. Phil Research Scholar, Department of Political Science, Shah Abdul Latif University, Khairpur, Sindh, Pakistan (e-mail: alinawaz.soomro@salu.edu.pk).

In this way Pakistan lost its big portion of its East Wing. In this connection, On December 20th 1971 President General Yahya Khan resigned, in the result Zulifquar Ali Bhutto became the new President and Civilian Chief Martial Law administrator of Pakistan[2].

\section{ASSASSINATION OF Z.A. BHUTTO AND MRD}

In 1977 she listened the bad news that her father's Government was overthrown in a Military quo by General Zia-ul-Haq and then her father was arrested in Muhammad Ahmed Khan Kauri's murder case, the case was filed by Ahmed RazaKasuri the son of Muhammad Ahmed Khan Kasuri, and in this way keeping in view "Gen. Zia-ul-Haq imposed third martial law 5th July 1977'[2]. During the whole period Zulifquar Ali Bhutto was of the opinion that the charges against him in the case were baseless, but the supporters of zia in lahore high court declared Bhutto guilty of murder case and death sentence was declared and finally on April $4^{\text {th }}, 1979$ he was hanged [3]. Assassination of Z. A Bhutto on 4th April 1979 was a great shock for his family as well as for the whole country; soon after execution Benazir and her all family members were put under house arrest in Karachi. After that she became Co-Chairperson of Pakistan People's Party (PPP) along with Begum Nussrat Bhutto as Chairperson in the Place of Zulifquar Ali Bhutto, because Benazir Bhutto was young and energetic at that time and at the same time Begum Nussrat Bhutto was in shock of her husband due to that reason she was unable to concentrate on the politics as Benazir Bhutto could. The years which followed her father's assassination created were very much difficult situation for her as well as for her family, so as a co-chairperson of Pakistan People's Party, Benazir Bhutto started the struggle from prison for the restoration of democratic government in Pakistan.

During this struggle consequently, including 10 months in detention, she remained about 5 years in the jail and which was not easy time for her because during this she also faced her father's death [4].

After some time she was released for a short period and during that period an alliance was formed for the restoration of democracy. "The first official meeting of the leaders for the formation of Alliance was held at 70 Clifton Karachi on 6th February 1981. The leaders were agreed and the alliance was formed and named Movement for the Restoration of Democracy (MRD). The following political parties formed the alliance.

- Pakistan People's Party

- Pakistan Muslim League (KhawajaKhairUddin Group)

- Pakistan Democratic Party

- Pakistan MazdoorKisan Party

- Pakistan National Party

- National Awami Party

- QuomiMahaz-e-Azadi 
- Jamiat-i-Ulema-i-Islam (JUI)

- Tahrik-i-Istiqlal (TI)

- National Democratic Party

Alliance sponsored a four point program: End of Martial Law; Restoration of the 1973 Constitution; Parliamentary elections; and Transfer of power to the public representatives" [5], soon after starting of MRD, Benazir was another time arrested and sent to jail but under international pressure she was released in the year 1984, after that she left Pakistan and went to UK and worked for MRD from there. She lived there for hardly two years, when her younger brother Shah Nawaz Bhutto was assassinated in France, she returned to Pakistan for burial of her brother and again she had to leave the country.

\section{HER EFFORTS FOR DEMOCRACY}

During these days she decided to continue the mission of her father, so for this purpose she once again planned to comeback to Pakistan, to pressurize General Mohammed Zia-ul-Haq for restoration of Democracy in the country. She landed in Lahore on April 11th, 1986 to fulfill her promises, "The carefree girl who first left home in 1969 to study at Harvard had now turned into a woman with an iron will, to fight the battle left incomplete by her father" [6]. Basically her ambition was to join Pakistan's foreign services, not to become a politician, she was of the opinion that her tendency was not towards politics, it was her father to whom she wanted to please by joining oxford union [7].

Benazir Bhutto was warmly welcome by millions of peoples at Lahore airport, General Zia had fear from it and due to his fear he played a card of Islamization and announced for referendum, Benazir Bhutto hoped for change for democracy in Pakistan but Gen. Zia-ul-Haq also made his clear intention that power would be transferred to only those persons which are religious minded, Gen. Zia-ulHaq's so called democracy shunned down when on 14 August 1986 Benazir Bhutto was arrested at her home in Karachi, when she was just preparing to attend peaceful rallies on Pakistan's Independence day. She was given thirty days detention order and once again she was send to jail. On other hand, except Jamat-i-Islami all the other political parties had already joined the alliance (MRD), they once again arose against the brutal killing of innocent peoples in lump sum and arrest of thousands of peoples by their own military. During movement Zia was worried because he was thinking, if Benazir Bhutto came in power then what will be his position? So he every time avoided the elections in Pakistan, while giving an interview General Zia replied, "It is Miss Bhutto's unnecessary impractical ambition and her attitude towards acquiring power which is objectionable" [8].

Unwillingly under International pressure and the MRD, Zia had to release the Benazir and she was released on 10th September 1986, but many people remained in jail. This struggle was intensified against Gen. Zia-ul-Haq by PPP along with other political parties under Benazir's guidance. LubnaRafique wrote, while PPP gained its full strength as single political institution in Pakistan, on other hand Zia denied these facts, "Bhutto retaliated against this by saying that her party was speaking not out of vengeance, but for nation building" [9].

After a long struggle Zia announced the elections, the good step taken by General Zia-ul-Haq through which he made Junejo as Prime Minister, that step once again gone into the darkness when Zia abolished the assemblies under article 58-2(b) on May $29^{\text {th }} 1988$, after that he announced that the new election will be held on November $16^{\text {th }}$ 1988[10]. This news was the hope of democracy for the Benazir and other political parties but Gen. Zia-ul-Haq announced on 21st July, 1988 that the elections would be held purely on nonparty basis; the reason was that the PPP has popular support, there was a reason behind the elections on non-party, Chandio Amir Ali writes: "Zia preferred the non- party elections because he was well-aware of the fact that nonpolitical and non-committed people are easy to control as compare to political and affiliated peoples. So he wanted that elected member of assemblies had no political association as well as membership of any political party or loyalty to any political leader" [11], now Benazir went to the courts and she challenged the Zia's nonparty based election, because she was of the opinion that in this way the military rule of Gen. Zia will come to an end and the democracy will be restored, she wrote, "Just as a flower cannot bloom in a desert, so political parties cannot flourish in a dictatorship" [12]. In this way the democracy is essential for the political parties where they can work freely without any hindrance and perform their political activities in a good manner, on other hand, in dictatorship there is no way for the political parties because history witnessed that the dictators tried their best just to extend their rule instead of giving opportunities for the democratic environment.

It was the Benazir Bhutto, for about thirty months she continued to mobilize world opinion for the restoration of democracy and violation of human rights by Zia. Zia wanted to keep the Benazir away from contesting the election, the election date was suggested by keeping in the view the pregnancy of Benazir Bhutto, so that she may not be able for election campaign [13].

\section{DEATH OF MuHAMmad ZIA-UL-HAQ}

"However, the rule of Zia-ul-Haq ended abruptly on 17th August 1988, when his C-130 Aircraft exploded shortly after taking off from the Bahawalpur Airport. This disaster also claimed the lives of five Generals, five Brigadiers, one Squadron Leader, an American Ambassador and fourteen members of crew"[14], the report conformed the Zia's death in air crash came on T.V and Radio in the same evening, "C-130 exploded 10 minutes after it took off from Bahawalpur, 60 miles west of the Indian border, at about 4:30 P.M"[15], Microsoft Encarta Encyclopedia describes that "In 1988 Zia was killed in an airplane crash possibly caused by sabotage"[16], and whole Pakistan went into a state of shock, even those who disliked General Zia-ul-Haq immensely and had waited for such news, they did not know how to react.

Benazir Bhutto's reaction on the death of Gen. Zia-ulHaq was not so special. The New York Times however 
quoted Benazir's expression that, "life and death is in the hands of God" [17], though, for the purpose of keeping Benazir Bhutto (PPP) away from power, a group of political parties formed Islami Jamhoori Ittehad (I.J.I) which included fundamentalists and Gen. Zia-ul-Haq's loyal, on the same night Chairman Senate Ghulam Ishaque Khan took reins of the country. He also announced November 16, 1988 the same date which was already planned for elections but he didn't clear that elections would be held on party basis or on non-party basis. Though the case filled by Benazir was in court against non-party based elections, and after the death of zia the court passed the verdict that the elections will be held on party basis, in this way the "general elections to the National Assembly and Provincial Assemblies were held on 16th November 1988 and 19th November 1988, respectively on Party Basis" [18]. So, on November 16, 1988 the Pakistani nation went on polls and PPP got majority seats in National Assembly by winning 93 out of 205 seats contested. The appointment of Benazir Bhutto as Prime Minister of Pakistan was an historic moment, in this way Benazir became the first lady Prime Minister in Muslim State at the age of 35 years. It was the moment when the entire world's attention was focused on this event. The turn of democracy in Pakistan after eleven years of one-man rule offered hope to the million, who voted for Benazir Bhutto, she is considered as the symbol of freedom and justice for poor Pakistani peoples.

Bhutto family is the only family in Pakistan, which sacrificed the whole family for the stable democratic system in Pakistan, "Goher Jamal, said no ideology could succeed without sacrifices and Bhutto family had given historic sacrifices for democracy and they all would be long remembered"[19], she spent her whole life in fighting for the rights of common people, democracy, stable political system, foreign Policy and on 27th December 2007 she was assassinated, while returning from Rawalpindi's LiaquatBagh, where she addressed the public gathering.

\section{CONCLUSION}

Pakistan is a democratic government, but unfortunately Pakistan has spent long time under martial law regimes and in the history of democracy the name of Benazir Bhutto would be remembered, the reason was Benazir Bhutto being a lady mobilized world opinion and fought for the peoples of Pakistan through the Democratic Movement against the dictator General Zia, during this period she started the movement for the restoration of democracy and against the violation of human rights. after the death of General ZiaulHaq in air crash, the general election were held in Pakistan, through which Pakistan People's Party emerged as the largest party in National Assembly and she became the first lady Prime Minister on 2nd December 1988, She became the Prime Minister of Pakistan two times in 198890 and 1993-96. She struggled the whole life for the democracy because she knew that it is the only democratic government which provide people's participation in government, people participate in government through their elected representative, which they elect through their right to vote and this right to vote makes the representatives answerable towards common people and on other hand martial law is the opposite of democracy, in which political rights are suspended, generally without democracy the concept of good governance is meaningless, because democracy is the assurance of people's participation which is the key element of good governance.

\section{REFERENCES}

[1] B. Craig., "Bangladesh," Microsoft ${ }^{\circledR}$ Encarta ${ }^{\circledR} 2009$ [DVD], Redmond, WA: Microsoft Corporation, 2008.

[2] D. W. Muhammad, Who is Who \& Who is What, World \& Pakistan, Lahore: Dogar Publishers, 2005.

[3] H. James, "Zulfikar Ali Bhutto," Microsoft $\AA^{\circledR}$ Encarta® 2009 [DVD], Redmond, WA: Microsoft Corporation, 2008.

[4] K. A. Ahmed and I. A. Choudhry, "Benazir Bhutto's Stuggle for Democracy," European Journal of Social Sciences, vol. 10, no. 1, pp. $162-165,2009$.

[5] A. A. Chandio, F. Naseem, and M. Ahmed, "Struggle for Democracy in Sindh: A Case Study of Movement for the Restoration of Democracy (1983)," Berkeley Journal of Social Sciences, vol. 1, no. 1, pp. 1-14, Jan 2011.

[6] R. Lubna, Benazir and British Press: 1986-1994, Lahore: Gautam Publisher, 1994

[7] B. Benazir, Daughter of the East, London: Hamilton, 1988.

[8] The New York Times, August 26th, 1986.

[9] R. Lubna, Benazir and British Press: 1986-1994, Lahore: Gautam Publisher, 1994.

[10] K. A. Ahmed and I. A. Choudhry, "Benazir Bhutto's Stuggle for Democracy," European Journal of Social Sciences, vol. 10, no. 1, pp, $162-165,2009$.

[11] A. A. Chandio, "Non-Party Based General Election of 1985: Causes and Effects," in Proc. 2011 International Conference of Social Science and Humanity, Singapore: IPEDR, vol. 5, V2-511-V2-513, 2011.

[12] B. Benazir, Daughter of the East, London: Hamilton, 1988.

[13] P. L. Bhola, Benazir Bhutto: opportunities and challenges, New Delhi: Yuvraj Publishers, 1989.

[14] S. E. Ullah, Pakistan Affairs, Lahore: Dogar Publisher, 2009-10.

[15] S. Elaine. (August 18, 1988). ZIA OF PAKISTAN KILLED AS BLAST DOWNS PLANE; U.S. ENVOY, 28 OTHERS DIE. [Online]. Available:

http://www.nytimes.com/1988/08/18/world/zia-of-pakistan-killed-asblast-downs-plane-us-envoy-28othersdie.html?pagewanted=all\&src=pm

[16] M. Z. Ul-Haq, Microsoft $₫$ Encarta 2009 [DVD], Redmond, WA Microsoft Corporation, 2008.

[17] The New York Times, August 18th, 1988.

[18] S. E. Ullah, Pakistan Affairs, Lahore: Dogar Publisher, 2009-10.

[19] Times Daily. (January 09, 2008). Benazir Bhutto's struggle for democracy praised. [Online]. Available: http://www.dailytimes.com.pk/default.asp?page=20081011091story_91-2008_pg7_57

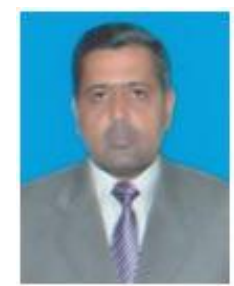

Amir Ahmed khuhro is the Professor in Department of International Relations, and the Director Shaheed Benazir Bhutto Chair at Shah Abdul Latif University, Khairpur, Dr. Khuhro was born on March 27th, 1966 at District Khairpur, Sindh, Pakistan, Dr. Khuhro has done his Ph. D from BahauddinZakaria University (BZU) Multan, Pakistan in 2009 in the field of Political Science. Currently he is working as a Professor in the Department of International Relations, Shah Abdul Latif University, Khairpur, Sindh, Pakistan, he is the author of two books(1. Personality as factor in foreign policy making: a case study of Pak-US relations during Benazir Bhutto's Periods, Published by Lambert Academic Publishing Germany, 2. Benazir Bhutto (Life and trends in foreign policy), Published by Lambert Academic Publishing Germany] a part from that he has published more than 20 research papers in various national and international journals and also presented research papers in international conferences. Moreover, his fields of specialization are Foreign Policy, Politics of South Asia, Nuclearization. Currently, Prof. Dr. Khuhro is the Senior member International Economic Development Research Center (IEDRC) Research Organization, Member Senate, Member Academic Council, Member Board of Advance Studies and Research Department of 
International Relations, Political Science \& Pakistan Studies Shah Abdul Latif University, Khairpur, Member Editorial Board Aftican journal of Political Science and International Relations (AJPSIR), Member Editorial Board Journal of Political Science and International Relations (GJPSIR), Editor in Chief of Peak Journal of Social Sciences and Humanities (PJSSH), Member Editorial Board International Science and Investigation Journal (ISIJ), Member Editorial Board IOSR Journal of Humanities and Social Science.

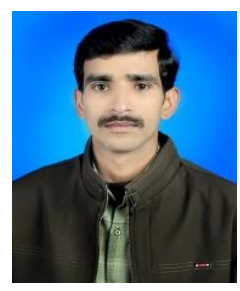

Ali Nawaz Soomro is teaching assitant in the Department of Political Science at Shah Abdul Latif University, Khairpur, Sindh Pakistan, Mr. Soomro was born on April 1st, 1986 at Khairpur, Sindh, Pakistan. Mr. Soomrohas received his Master's Degree From Shah Abdul Latif University, Khairpur In the Department of Political Science. Currently he is doing his M.Phil Degree in Political Science from Shah Abdul Latif University,
Khairpur, he has attended one national and one international conference and his research paper was published in International Journal of Contemporary Research in Business, his fields of specializations are Local Government, Good Governance and Human Rights.Currently, Mr. Soomro is the Program Team member of QEC (Quality Enhancement Cell) Shah Abdul Latif University, Khairpur. Mr. Soomro was awarded silver medals for securing first class first in B.A (Hon's) and M.A level as well. 